\title{
Susceptibility of colonies and colonial cells of Phaeocystis pouchetii (Haptophyta) to viral infection
}

\author{
Anita Jacobsen ${ }^{1, *}$, Aud Larsen ${ }^{1}$, Joaquín Martínez-Martínez ${ }^{2}$, Peter G. Verity ${ }^{3}$, \\ Marc E. Frischer ${ }^{3}$ \\ ${ }^{1}$ Department of Biology, University of Bergen, PO Box 7800, 5020 Bergen, Norway \\ ${ }^{2}$ Department of Biological Oceanography, NIOZ, PO Box 59, 1790 AB Den Burg, Texel, The Netherlands \\ ${ }^{3}$ Skidaway Institute of Oceanography, 10 Ocean Science Circle, Savannah, Georgia 31411, USA
}

\begin{abstract}
Viruses play a significant role in the microbial food web, as controlling agents in community composition and succession, and in termination of blooms. The flagellated stage of the polymorphic Phaeocystis pouchetii (Hariot) Lagerheim was previously shown to be readily infected by the species-specific PpV-virus. In the present study, we investigated if colonial cells of $P$. pouchetii were susceptible to virus infection and if the growth stage of the host population affected viral infectivity, based on 2 types of observations: incubation experiments with natural $P$. pouchetii colonies and added viral concentrate, and monitoring viral abundance during 2 different growth seasons in large outdoor mesocosm experiments. In the incubation experiments, colonial cells of $P$. pouchetii at various growth stages, embedded in and detached from the mucus, were inoculated with different concentrations of PpV-AJ96. Viral lysis of colonial P. pouchetii cells was not observed, regardless of virus concentrations and stage of $P$. pouchetii colony growth. However, flagellated cells of $P$. pouchetii were readily infected with the same virus strain. In the mesocosm sampling studies, the development of populations of PpV-like particles along with a bloom of $P$. pouchetii was followed in 2 separate growth seasons. These studies showed a dynamic PpV-like abundance over time that was closely linked to the host population. PpV-like viruses were present and readily detected in both mesocosm experiments in which $P$. pouchetii appeared. The results from these experiments suggest that colonial cells of $P$. pouchetii were not infected by the virus strain PpV-AJ96 and that the colonial stage of $P$. pouchetii provides protection against viral infection.
\end{abstract}

KEY WORDS: Phaeocystis pouchetii $\cdot$ Colonies $\cdot$ Virus

Resale or republication not permitted without written consent of the publisher

\section{INTRODUCTION}

Viruses are abundant in marine ecosystems, where they significantly affect microbial food webs (e.g. Fuhrmann 1999, Suttle 2000, Brussaard 2004). Viruses infecting phytoplankton have been demonstrated to play an important role in bloom dynamics (e.g. Zingone 1995), as controlling agents in community composition and succession (Wommack \& Colwell 2000, Larsen et al. 2001), as well as in the termination of phytoplankton blooms (Bratbak et al. 1993, Nagasaki et al. 1994, Castberg et al. 2001, Jacquet et al. 2002, Brussaard 2004).
Species from the genus Phaeocystis Lagerheim have a worldwide distribution and may form dense blooms (e.g. Lancelot et al. 1994) that can alter material flow among trophic levels and export from the upper ocean (Wassmann et al. 1990, Lancelot et al. 1998). Transitions between colonial and solitary cell stages are the rule within the genus (e.g. Kornmann 1955, Rousseau et al. 1994, Jacobsen 2002). The gelatinous colonial stage is readily recognized as it produces prodigious blooms and has therefore received attention in numerous investigations worldwide (e.g. Davidson \& Marchant 1992, Lancelot et al. 1994, Nejstgaard et al. 2006). Blooms of the colonial 
stage of $P$. pouchetii occur regularly in spring in Norwegian waters (Eilertsen et al. 1981, Jacobsen 2000, Wassmann et al. 2005). Several studies (e.g. Jacobsen et al. 1996, Bratbak et al. 1998) have shown the flagellated stage of $P$. pouchetii to be extremely susceptible to viral mortality, which could thereby explain the apparently insignificant abundance of this morphotype in Norwegian waters.

A virus specific for Phaeocystis pouchetii (PpVAJ96), isolated and maintained in culture for over a decade (Jacobsen et al. 1996), is capable of lysing flagellated cells of $P$. pouchetii (Jacobsen et al. 1996, Jacobsen 2000). Both flagellated cells and non-flagellated colonial cells of the closely related species $P$. globosa Scherffel are also susceptible to viral infection when not embedded in mucus (Baudoux \& Brussaard 2005). It has been shown that the outer membrane of colonies of $P$. globosa possesses 1 to $4.4 \mathrm{~nm}$ large pores, which are smaller than the size of the $P$. globosa viral particle $(\mathrm{PgV})$ and may thus act as mechanical protection against viral infection (Hamm et al. 1999).

The purpose of the present study was to elucidate, for the first time, if colonial cells of Phaeocystis pouchetii were susceptible to virus infection, and also if the growth stage of the host population influenced infectivity. Both intact colonies and colonial cells detached from the mucus were inoculated with different concentrations of PpV-AJ96 at various growth stages. In addition, the development of the virus population during a bloom of $P$. pouchetii was followed in 2 separate mesocosm experiments (2002 and 2003).

\section{MATERIALS AND METHODS}

The present study includes 2 types of experiments: (1) infection experiment using wild Phaeocystis pouchetii colonies and cultured $P$. pouchetii-specific viruses, and (2) sampling of $P$. pouchetii and $P$. pouchetii viral-like particles during 2 growth seasons in large outdoor mesocosms.

Infection experiment. Four virus-infection experiments (Expts 1 to 4 ) were conducted in 2003 to see if viruses infected colonial cells embedded in mucus and/or detached from the mucus. The virus strain used in Expts 1 to 4 (PpV-AJ96) was obtained from the virus collection at the Department of Biology (University of Bergen, Norway). The virus was isolated in 1995 and has proven specific for Phaeocystis pouchetii (Jacobsen et al. 1996). Prior to each colony infection experiment, a fresh virus lysate was counted by flow cytometry (FCM) in order to give an accurate number of viruses added. Keeping $P$. pouchetii as colonies in a laboratory culture is difficult and to our knowledge there is no such culture available. Accordingly, we used $P$. pouchetii colonies from various stages of bloom development collected during a mesocosm experiment in 2003, in which colonies of P. pouchetii dominated the phytoplankton community (Nejstgaard et al. 2006). The colonies used in the infection experiments described below were obtained from mesocosm $\mathrm{NPb}$ (see 'Mesocosm sampling' for further details).

Expt 1: Expt 1 was conducted in the early exponential stage of the Phaeocystis pouchetii mesocosm bloom, starting on Day 10 (see Fig. 4). A sample of mesocosm water $(4 \mathrm{ml})$ containing an average number $( \pm \mathrm{SD})$ of $1.5 \pm 0.5$ colony ml ${ }^{-1}(\mathrm{n}=5)$ and a mean of $112 \pm 9$ cells colony ${ }^{-1}$ was added to each of 12 wells in 5 Nunc culture plates. The number of cells per colony was estimated according to Verity et al. (2007a). Each of the 12 wells in the 5 Nunc culture plates were then inoculated with PpV-AJ96 corresponding to a final concentration of $10^{8}, 10^{7}, 10^{6}, 10^{5}$ and $0 \mathrm{ml}^{-1}$, respectively, with a virus-to-host ratio ranging from 0 to 892 857. The multiplicity of infection (MOI) was not measured, but the infectivity of the viruses employed in this study was earlier reported to be 1 to $10 \%$ (Bratbak et al. 1998). Colonies of $P$. pouchetii rupture easily in contrast to P. globosa; hence, to obtain detached colonial cells, a $100 \mathrm{ml}$ mesocosm water sample was shaken vigorously and a $4 \mathrm{ml}$ sample was added to each of 12 wells in 1 Nunc culture plate containing an average number of $214 \pm 87$ cells ml$^{-1}$. In addition, $4 \mathrm{ml}$ of an exponentially growing culture of flagellated cells (strain AJ01, Jacobsen et al. 1996) containing an average number of $10.5 \times 10^{4} \pm 8721 \mathrm{cells} \mathrm{ml}^{-1}$ was added to each of 12 wells in 1 Nunc culture plate. Each of the 12 wells in these 2 Nunc culture plates was then inoculated with PpV-AJ96 corresponding to a final concentration of $10^{8} \mathrm{ml}^{-1}$. Every plate was inspected and $P$. pouchetii counted each day for $5 \mathrm{~d}$. Colonial $P$. pouchetii was counted under a dissection microscope (Wild M10). Flagellated and detached colonial cells were inspected and counted under a Leitz Dialux-20 light microscope with phase contrast at $400 \times$ magnification using a Fuchs Rosenthal haematocytometer with a counting error of $\pm 10 \%$ (Andersen \& Throndsen 2003).

Expt 2: Expt 2 was conducted in the exponential stage of the Phaeocystis pouchetii mesocosm bloom starting on Day 18. A $2 \mathrm{ml}$ mesocosm water sample containing an average of $49 \pm 5$ colonies $\mathrm{ml}^{-1}$ and an average of $154 \pm 12$ cells colony ${ }^{-1}$ was added to each of 12 wells in 5 Nunc culture plates. Each of the 12 wells in the 5 Nunc culture plates was then inoculated with PpV-AJ96 corresponding to a final concentration of $10^{8}, 10^{7}, 10^{6}, 10^{5}$ and $0 \mathrm{ml}^{-1}$, respectively. The initial concentration of detached colonial and flagellated cells contained an average of $336 \pm 16$ and $13 \times 10^{4} \pm 13588$ 
cells $\mathrm{ml}^{-1}$, respectively. The virus-to-host ratio ranged from 0 to 16233 . For experimental design, sampling procedures, inspection and counting: see description of Expt 1.

Expt 3: Expt 3 was conducted in the early stationary stage of the Phaeocystis pouchetii mesocosm bloom starting on Day 25. A $1 \mathrm{ml}$ mesocosm water sample containing an average of $96 \pm 16$ colonies $\mathrm{ml}^{-1}$ and an average of $210 \pm 16$ cells colony $^{-1}$ was added to each of 12 wells in 5 Nunc culture plates, each of which were then inoculated with PpV-AJ96 corresponding to a final concentration of $10^{8}, 10^{7}, 10^{6}, 10^{5}$ and $0 \mathrm{ml}^{-1}$, respectively. The initial concentration of detached colonial and flagellated cells contained an average of $532 \pm 21$ and $10.5 \times 10^{4} \pm 8721$ cells ml${ }^{-1}$, respectively. The virus-to-host ratio ranged from 0 to 4762 . For experimental design, sampling procedures, inspection and counting: see description of Expt 1.

Expt 4: Expt 4 was conducted at the collapse of the Phaeocystis pouchetii mesocosm bloom starting on Day 32. A $1 \mathrm{ml}$ mesocosm water sample containing an average of $205 \pm 18$ colonies $\mathrm{ml}^{-1}$ was added to each of 12 wells in 5 Nunc culture plates. Unfortunately, the number of cells per colony was not counted in this experiment; therefore, the virus-to-host ratio is not given. Each of the 12 wells in the 5 Nunc culture plates was then inoculated with PpV-AJ96 corresponding to a final concentration of $10^{8}, 10^{7}, 10^{6}, 10^{5}$ and $0 \mathrm{ml}^{-1}$, respectively. The initial concentration of detached colonial and flagellated cells contained an average of $727 \pm 18$ and $12 \times 10^{4} \pm 22500$ cells ml $^{-1}$, respectively. For experimental design, sampling procedures, inspection and counting: see description of Expt 1.

Mesocosm sampling. Sampling for Phaeocystis pouchetii and $P$. pouchetii viral-like particles was part of major mesocosm studies carried out in March to April 2002 and 2003 at the Marine Biological Field Station, University of Bergen, Norway (Nejstgaard et al. 2006, Verity et al. 2007a,b). Two sets of experiments, each consisting of three $11 \mathrm{~m}^{3}$ enclosures, were mounted on floating frames moored to a raft (see Nejstgaard et al. 2006 for further details). Two of the enclosures were initially fertilized with nitrate $\left(\mathrm{NaNO}_{3}\right)$ and phosphate $\left(\mathrm{KH}_{2} \mathrm{PO}_{4}\right)$, corresponding to increases of $16 \mu \mathrm{M}$ nitrate and $1 \mu \mathrm{M}$ phosphate, and one served as a control without nutrient addition. Each day, 10\% of the enclosure volume was renewed along with $10 \%$ of the initial nutrient load. All of the enclosures were amended with the same initial nutrient concentration, except for the controls. In the 2002 experiment, both nutrient-enriched enclosures were augmented with $8 \mu \mathrm{M}$ nitrate and $0.5 \mu \mathrm{M}$ phosphate on Day 9 due to low nutrient concentrations. The mesocosms were named control, NP and NPF in 2002 and control, NPa and NPb in 2003, where NP corresponds to nitrate (N) and phosphate (P) amended mesocosms in both years, and $\mathrm{F}$ corresponds to added flagellated cells (in 2002 only; see below).

To investigate if higher initial abundance of flagellated cells would induce more or earlier colony formation, a $40 \mathrm{l}$ culture of Phaeocystis pouchetii flagellated cells $\left(8.25 \times 10^{4}\right.$ cells $\left.\mathrm{ml}^{-1}\right)$ was added to mesocosm NPF (only in 2002), resulting in a final concentration of flagellated cells of 300 cells $\mathrm{ml}^{-1}$. The initial native flagellated population of $P$. pouchetii was ca. 200 cells $\mathrm{ml}^{-1}$. The culture of $P$. pouchetii flagellated cells was originally isolated from Raunefjorden in 2001 and grown in f/2-Si media (Guillard 1975) at a salinity of $31 \%$.

The development of virus populations was followed along with blooms of Phaeocystis pouchetii in the mesocosm experiments in both years, except in the control mesocosm in 2002. Flagellated cells and colonies of $P$. pouchetii were counted as described in Nejstgaard et al. (2006), and viruses were counted by means of FCM. For FCM analyses, seawater samples were fixed with glutaraldehyde $(0.5 \%$ final concentration), frozen in liquid nitrogen and stored at $-70^{\circ} \mathrm{C}$ (Marie et al. 1999b). After thawing, the samples were stained with SYBR Green I (Molecular Probes) and analyzed according to Marie et al. (1999a) using a FACSCalibur FCM (Becton Dickson). The discrimination of virus subtypes was based on groupings observed in scatter plots of SSC signal versus green DNA-dye (SYBR Green) fluorescence (see Fig. 3). Datafiles were analyzed using CYTOWIN (Vaulot 1989, available at www.sb-roscoff.fr/Phyto/index.php) and EcoFlow (version 1.0.5, available from the authors).

Water samples from mesocosms NPF (2002) and NPb (2003) were collected on a regular basis and used to inoculate growing cultures of $P$. pouchetii (AJ01), to test for presence of functionally infective $P$. pouchetii viruses. These samples were also analyzed by FCM for populations of virus and bacteria.

\section{RESULTS}

\section{Infection experiments}

The results from the virus infection experiments in which intact colonies were infected with PpV-AJ96 showed no reduction in the number of colonies present (Fig. 1). There were no signs of cell lysis within the colonies during the different stages of growth (Expts 1 to 4). On visual inspection the cells appeared healthy, and the number of colonies stayed relatively stable from the start of each experiment until termina- 


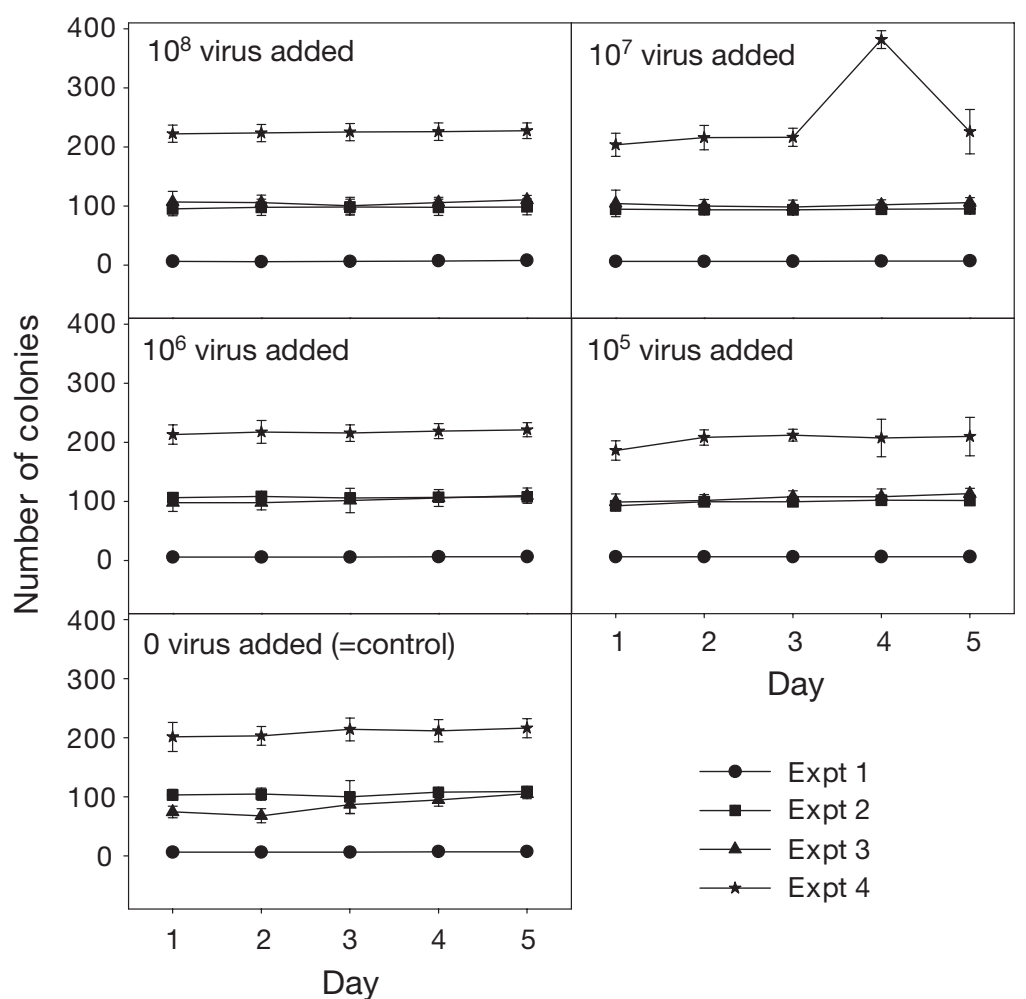

Fig. 1. Phaeocystis pouchetii. Time series during 4 different infection experiments with colonial cells of $P$. pouchetii embedded in mucus at different virus concentrations added (0 to $10^{8}$ virus $\left.\mathrm{ml}^{-1}\right)$ and at different growth stages of the host population. Numbers are mean colonies per well $\pm \mathrm{SD}, \mathrm{n}=12$

tion $5 \mathrm{~d}$ later. None of the dilution treatments or the different growth stages of the host populations were affected by virus addition $\left(10^{8}\right.$ to $\left.10^{5} \mathrm{ml}^{-1}\right)$, and they were similar to the controls (Fig. 1). One exception, however, was the colony abundance in the $10^{7}$ virus addition of Expt 4, which increased on Day 4, probably caused by a counting error as the abundance decreased the following day (Day 5). The virus infec- tion experiments with colonial cells detached from the mucus also did not reveal reductions in cell numbers caused by viral lysis. In contrast, the flagellated cells of $P$. pouchetii infected with PpV-AJ96 were completely lysed within $3 \mathrm{~d}$ (Fig. 2). Although the infection experiments were ended after $5 \mathrm{~d}$, all of the Nunc plates were inspected after an additional $10 \mathrm{~d}$ in order to detect a possible viral infection of the colonial cells. This was never observed (results not shown).

\section{Mesocosm studies}

A Phaeocystis pouchetii virus (PpV) was readily detected in mesocosm water in which P. pouchetii appeared (Fig. 3). In order to confirm the presence of $\mathrm{PpV}$-specific viruses in the mesocosm water we inoculated a flagellated $P$. pouchetii culture (strain AJ01) with water from mesocosms NPF (2002) and $\mathrm{NPb}$ (2003). The cultures lysed within $2 \mathrm{~d}$ and the virus groups could be observed in FCM dot plots (Fig. 3A,C). A virus population with similar FCM signature to the previously isolated PpV-AJ96 (not shown) and PpV from these lysates (Fig. 3A,C) was observed in water samples directly from the mesocosms as well (Fig. 3B,D) and is hereafter called PpV-like particles.

PpV-like viruses appeared during and after blooms of Phaeocystis pouchetii in both mesocosm experiments (Figs. 3 \& 4). In the 2002 experiment, the PpVlike particles increased considerably as the bloom of $P$. pouchetii progressed (Fig. 4). This was also seen in the 2003 experiment, but the virus proliferation was delayed and more prominent after the bloom of $P$. pouchetii (Fig. 4).

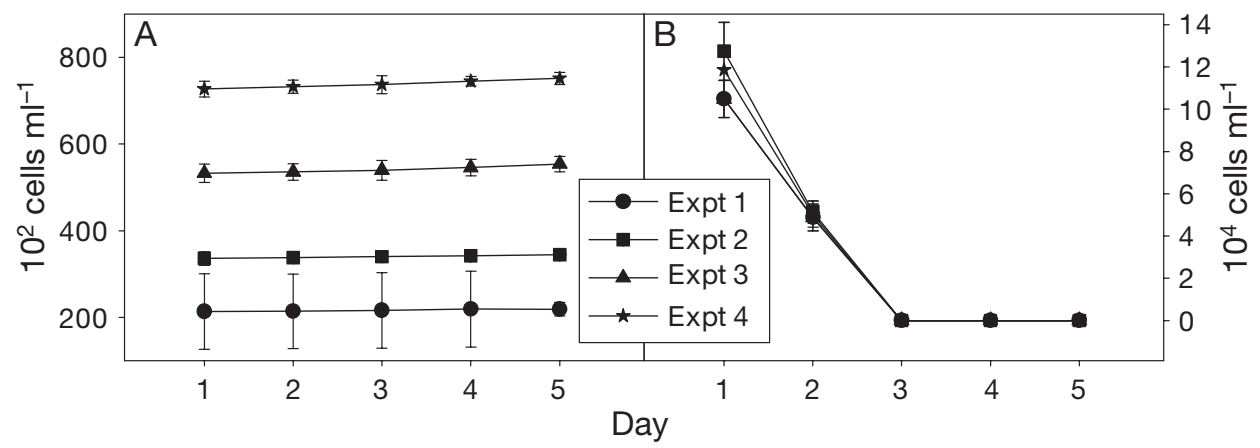

Fig. 2. Phaeocystis pouchetii. Time series during 4 different infection experiments adding viruses $\left(10^{8} \mathrm{ml}^{-1}\right)$ to $(\mathrm{A})$ detached colonial cells and (B) flagellated cells of $P$. pouchetii with host population in different stages of growth. Numbers are mean cells ml ${ }^{-1}$ $\pm \mathrm{SD}, \mathrm{n}=12$ 


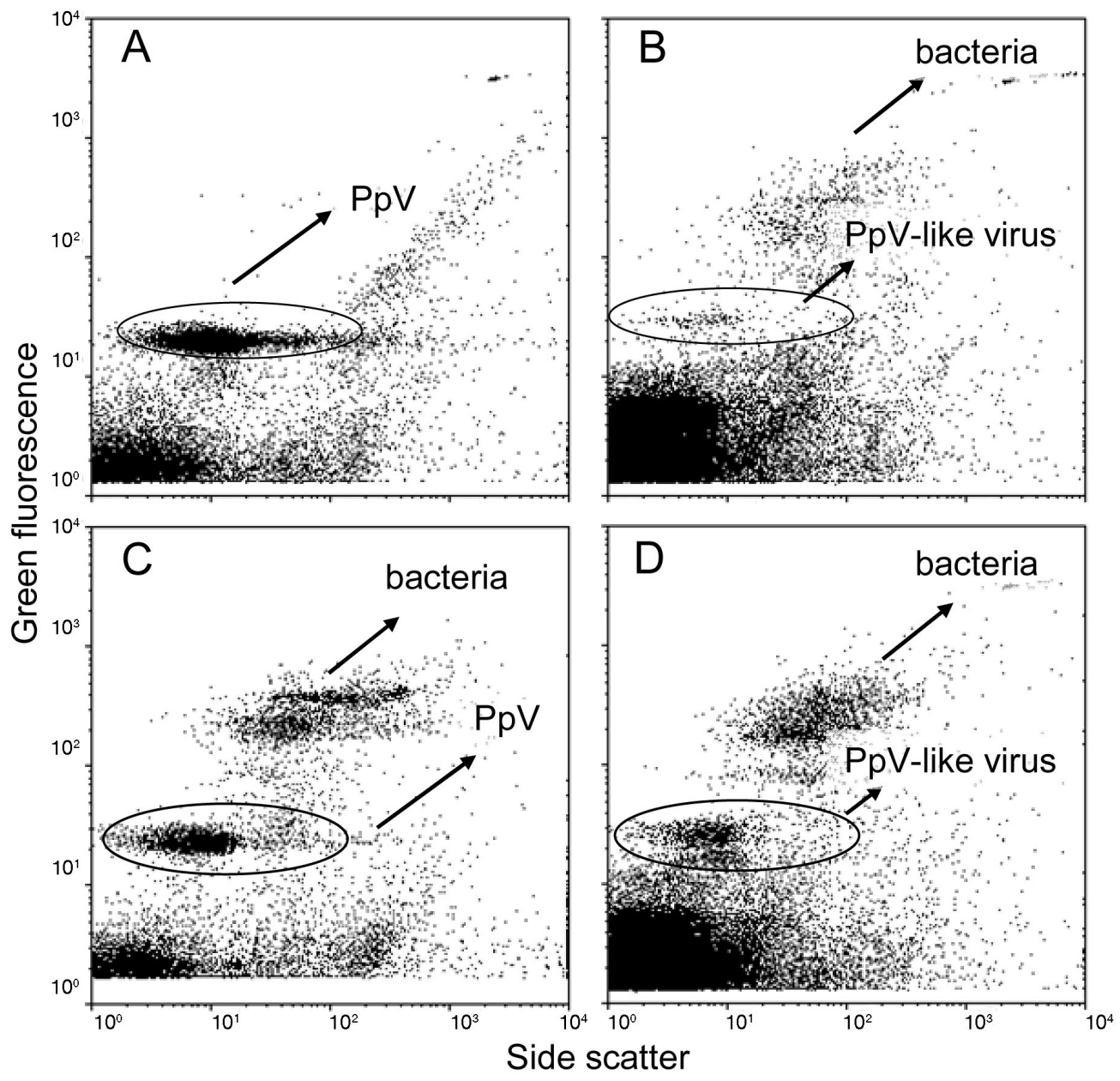

Fig. 3. Biparametric flow cytometry plots showing populations of viruses and bacteria $(A, C)$ in lysates and $(B, D)$ in mesocosm samples. (A) Virus and bacteria in a lysate after inoculating Phaeocystis pouchetii culture with water from mesocosm NPF (26 March 2002). (B) Virus and bacteria in mesocosm NPF on 26 March 2002. (C) Virus and bacteria in a lysate after inoculating $P$. pouchetii culture with water from NPb (20 March 2003). (D) Virus and bacteria in mesocosm NPb on 3 April 2003. PpV: P. pouchetii virus

\section{DISCUSSION}

The results from the virus infection experiments imply that colonial cells of Phaeocystis pouchetii embedded in or detached from the mucus, regardless of the growth stage of the population, were not affected by viral lysis. One probable cause could be that the outer membrane of the colonies acts as mechanical protection against, for example, viruses and makes the cells inaccessible to viral infection (Hamm et al. 1999), permitting colonies to bloom. Brussaard et al. (2005) showed that the colonial form of $P$. globosa is an excellent mechanism to prevent viral infection. Modeling suggests that the relevant issue may be the size of the $P$. globosa colonies, which reduces the chance of infection per cell, as opposed to the mucus acting as a barrier (Ruardij et al. 2005), since when the diameter of the colonies increased the viral infection became insignificant. From this hypothesis, colonies should therefore be more susceptible to virus infection at an early stage of the bloom when the diameter is fairly small (e.g. Verity et al. 2007a,b), but this was not observed for $P$. pouchetii in the infection experiments. Even when the virus-to-host-cell ratio was higher when infecting colonies (8929 to 892857) compared to the virus-to-host-cell-ratio when infecting the flagellated cells (1000), viral infection of the colonies was not promoted.

Detached colonial cells of $P$. pouchetii were not susceptible to viral infection. In contrast, Baudoux \& Brussaard (2005) showed that one strain of P. globosa (detached colonial cells) was infected by the $\mathrm{PgV}$ virus and that it had a strain-specific spectrum of infection. They also showed that flagellated cells of P. globosa 


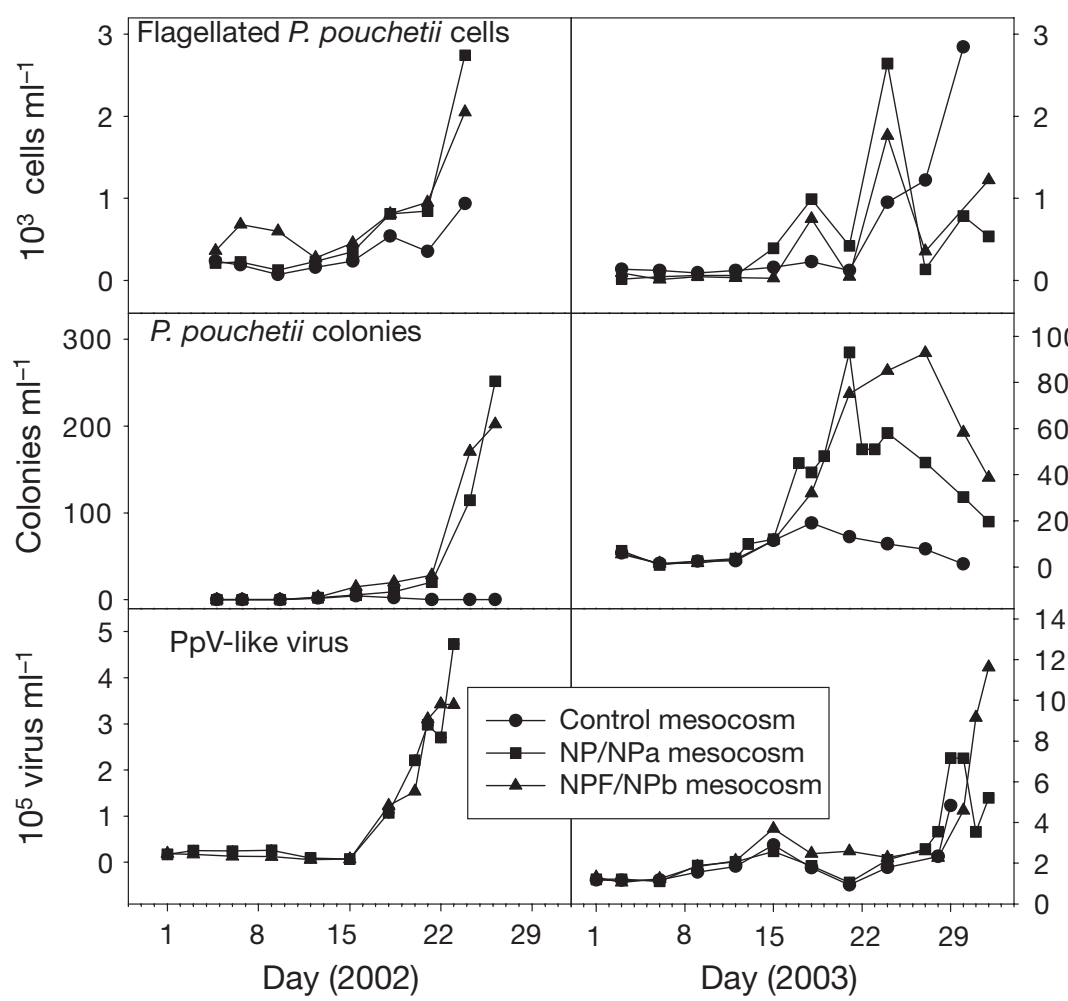

Fig. 4. Time series of flagellated cells and colonies of Phaeocystis pouchetii and PpV-like particles in 2 mesocosm experiments (2002 and 2003). Control = no nutrients added; $\mathrm{NP}, \mathrm{NPF}, \mathrm{NPa}, \mathrm{NPb}=$ nutrients added

were readily infected by the $\mathrm{PgV}$ and that the susceptibility of one strain was not constant over time. This is also in accordance with Nagasaki \& Yamaguchi (1998) and Nagasaki et al. (1999), who showed that some clones of Heterosigma akashiwo were resistant to viral infection and had different virus sensitivity. Thus it is possible that the lack of infection of colony cells in the present study reflects viral strain specificity. However, this seems unlikely given that (1) different strains of $P$. pouchetii were susceptible to viral infection in culture (e.g. Jacobsen et al. 1996), and (2) the results represent natural $P$. pouchetii populations undoubtedly containing multiple genetic lines (e.g. Verity et al. 2007c), and occurring over a 2 yr period.

Thus it is parsimonious to conclude from available evidence that only the flagellated cells of Phaeocystis pouchetii are infected by the $\mathrm{PpV}$ and therefore $\mathrm{PpV}$ only have the ability to affect bloom dynamics when the host organisms appears in the flagellated stage. A constant low abundance of viruses can theoretically prevent massive blooming of flagellated cells and thereby prevent colony formation from the flagellated cells (e.g. Jacobsen 2002). However, a small fraction of the flagellated population in nature may be, or even may develop, resistance to viral infection as shown by Thyrhaug et al. (2003). Such resistant populations can then form blooms of colonies under nonlimiting conditions (e.g. Nejstgaard et al. 2006) in order to escape grazing by zooplankton (Nejstgaard et al. 2007). Brussaard et al. (2005) showed that the 2 morphologies of P. globosa cells (flagellated and colonial) were differentially regulated by viral control. Under nonlimiting nutrient and light conditions blooms of colonies were formed. Viruses were found to be a significant loss factor, but could not prevent bloom formation. Under conditions that restricted colony formation and favoured the proliferation of flagellated single cells, viruses were found to prevent bloom formation. Flagellated cells of $P$. pouchetii can grow at relatively high rates (Jacobsen \& Veldhuis 2005, Wassmann et al. 2005) outside the blooming period in natural waters under different growth conditions, implying that viral infection of flagellated populations may take place at a relatively constant rate and regulate population growth.

The mesocosm studies showed a dynamic PpV-like abundance over time that was closely linked to the host population. A peak in PpV-like particles coincided with the peak of both colonies and flagellated cells in 2002, while in 2003 both colonies and flagellated cell collapses were linked to increased viral abundance.

It has been speculated that blooms of Phaeocystis pouchetii may be terminated by species-specific virus infection (Jacobsen 2000). However, there is strong evidence that viral lysis does not terminate colonial blooms of $P$. pouchetii (Nejstgaard et al. 2006) and that viruses do not infect colonial $P$. pouchetii cells (present study). At the peak of the $P$. pouchetii mesocosm blooms, flagellated cells were observed inside of the colonies, followed by proliferation of flagellated cells, which were possibly triggered by nutrient limitation (Whipple et al. 2005). This may explain the observed increase in free flagellated cells in the mesocosms, coinciding with the peak of the colonies. Both (1) the release of flagellated cells and (2) nutrient limitation preventing production of new colonies may therefore explain the decrease in colony numbers. Once the flagellated cells were liberated they became susceptible to viral infection, resulting in the observed increase in PpV-like particles. The modeling results of Ruardij et al. (2005) suggested that the fraction of infectious PgV was highest when single cells of $P$. globosa dominated the population. 
In conclusion, there were no signs of lysis of colonial Phaeocystis pouchetii cells embedded in mucus, regardless of virus concentration and growth stage of the host population. The flagellated cells were, however, readily infected. This suggests that the colony stage of $P$. pouchetii provides protection against viral infection and that the flagellated stage is vulnerable to viral infection and lysis. In an ecological perspective, colony formation by $P$. pouchetii may thus act as a defense mechanism against viral infection and/or grazing, and thereby escape a major mortality source. The extreme susceptibility of the flagellated cells can also be an explanation of the apparently insignificant abundance of this morphotype in Norwegian waters.

Acknowledgements. We thank the staff at the Marine Biological Field Station (University of Bergen, Norway) for their service while these studies were conducted. Funding was provided by USA National Science Foundation grants OPP00-83381 and OCE-05-45312, and Department of Energy grant FG02-98ER62531.

\section{LITERATURE CITED}

Andersen P, Throndsen J (2003) Estimating cell numbers. In: Hallegraeff GM, Anderson DM, Cembella AD (eds) Manual on harmful marine microalgae. UNESCO Publishing, Paris, p 99-129

Baudoux AC, Brussaard CPD (2005) Characterization of different viruses infecting the marine harmful algal bloom species Phaeocystis globosa. Virology 341:80-90

Bratbak G, Egge JK, Heldal M (1993) Viral mortality of the marine alga Emiliania huxleyi (Haptophyceae) and termination of algal blooms. Mar Ecol Prog Ser 93:39-48

Bratbak G, Jacobsen A, Heldal M, Nagasaki K, Thingstad F (1998) Virus production in Phaeocystis pouchetii and its relation to host cell growth and nutrition. Aquat Microb Ecol 16:1-9

Brussaard CPD (2004) Viral control of phytoplankton populations-a review. J Eukaryot Microbiol 51:125-138

Brussaard CPD, Kuipers B, Veldhuis MJW (2005) A mesocosm study of Phaeocystis globosa population dynamics. I. Regulatory role of viruses in bloom control. Harmful Algae 4: 859-874

Castberg T, Larsen A, Sandaa RA, Brussaard CPD and 5 others (2001) Microbial population dynamics and diversity during a bloom of the marine coccolithophorid Emiliania huxleyi (Haptophyta). Mar Ecol Prog Ser 221: $39-46$

Davidson AT, Marchant HJ (1992) The biology and ecology of Phaeocystis (Prymnesiophyceae). Prog Phycol Res 8:1-45

Eilertsen HC, Schei B, Taasen JP (1981) Investigations on the plankton community of Balsfjorden, Northern Norway. The phytoplankton 1976-1978. Abundance, species composition, and succession. Sarsia 66(2):129-141

Fuhrman JA (1999) Marine viruses and their biogeochemical and ecological effects. Nature 399:541-548

Guillard RRL (1975) Culture of phytoplankton for feeding marine invertebrates. In: Smith WL, Chanley MH (eds) Culture of marine invertebrate animals. Plenum Press, New York, p 29-60

Hamm CE, Simson DA, Merkel R, Smetacek V (1999)
Colonies of Phaeocystis globosa are protected by a thin but tough skin. Mar Ecol Prog Ser 187:101-111

Jacobsen A (2000) New aspects of bloom dynamics of Phaeocystis pouchetii (Haptophyta) in Norwegian waters. Dr Sci thesis, University of Bergen

Jacobsen A (2002) Morphology, relative DNA content and hypothetical life cycle of Phaeocystis pouchetii (Prymnesiophyceae); with special emphasis on the flagellated cell type. Sarsia 87:338-349

Jacobsen A, Veldhuis MJW (2005) Growth characteristics of flagellated cells of Phaeocystis pouchetii revealed by diel changes in cellular DNA content. Harmful Algae 4: 811-821

Jacobsen A, Bratbak G, Heldal M (1996) Isolation and characterization of a virus infecting Phaeocystis pouchetii (Prymnesiophyceae). J Phycol 32:923-927

Jacquet S, Heldal M, Iglesias-Rodriguez D, Larsen A, Wilson W, Bratbak G (2002) Flow cytometric analysis of an Emiliania huxleyi bloom terminated by viral infection. Aquat Microb Ecol 27:111-124

Kornmann P (1955) Beobachtungen an Phaeocystis-Kulturen. Helgol Wiss Meeresunters 5:218-233

Lancelot C, Wassmann P, Barth H (1994) Ecology of Phaeocystis-dominated ecosystems. J Mar Syst 5:1-4

Lancelot C, Keller MD, Rousseau V, Smith WO, Mathot S (1998) Autecology of the marine haptophyte Phaeocystis sp. In: Anderson DM, Cembella AD, Hallegraeff GM (eds) Physiological ecology of harmful algal blooms. NATO ASI Ser G, Vol 41, Springer, Berlin, p 209-224

Larsen A, Castberg T, Sandaa RA, Brussaard CPR and 6 others (2001) Population dynamics and diversity of phytoplankton, bacteria and viruses in a seawater enclosure. Mar Ecol Prog Ser 221:47-57

Marie D, Brussaard CPD, Thyrhaug R, Bratbak G, Vaulot D (1999a) Enumeration of marine viruses in culture and natural samples by flow cytometry. Appl Environ Microbiol 65:45-52

Marie D, Simon N, Brussaard CPD, Partensky F, Vaulot D (1999b) Enumeration of phytoplankton, bacteria and viruses in marine samples. In: Robinson JP, Darzynkiewicz Z, Dean PN, Orfao A and 4 others (eds) Current protocols in cytometry. John Wiley \& Sons, Chichester, p 11.11.1-11.11.15

Nagasaki K, Yamaguchi M (1998) Intra-species host specificity of $\mathrm{HaV}$ (Heterosigma akashiwo virus) clones. Aquat Microb Ecol 14:109-112

Nagasaki K, Ando M, Itakura S, Imai I, Ishida Y (1994) Viral mortality in the final stage of Heterosigma akashiwo Raphidophyceae red tide. J Plankton Res 16:1595-1599

Nagasaki K, Tarutani K, Yamaguchi M (1999) Cluster analysis on algicidal activity of HaV clones and virus sensitivity of Heterosigma akashiwo (Raphidophyceae). J Plankton Res 21:2219-2226

Nejstgaard JC, Frischer ME, Verity PG, Anderson JT and 11 others (2006) Plankton development and trophic transfer in sea water enclosures added nutrients and Phaeocystis pouchetii. Mar Ecol Prog Ser 321:99-121

Nejstgaard JC, Tang KW, Steinke M, Dutz J, Koski M, Antajan E, Long J (2007) Zooplankton grazing on Phaeocystis: a quantitative review and future challenges. Biogeochemistry 83:147-172

Rousseau V, Vaulot D, Casotti R, Cariou V, Lenz J, Gunkel J, Baumann M (1994) The life cycle of Phaeocystis (Prymnesiophyceae): evidence and hypotheses. J Mar Syst 5:23-39

Ruardij P, Veldhuis MJW, Brussaard CPD (2005) Modelling bloom dynamics of the polymorphic phytoplankter Phaeocystis globosa: impact of grazers and viruses. Harmful Algae 4:941-963 
Suttle CA (2000) Ecological, evolutionary, and geochemical consequences of viral infection of cyanobacteria and eukaryotic algae. In: Hurst CJ (ed) Viral ecology. Academic Press, San Diego, CA, p 248-296

Thyrhaug R, Larsen A, Thingstad TF, Bratbak G (2003) Stable coexistence in marine algal host-virus systems. Mar Ecol Prog Ser 254:27-35

Verity PG, Whipple SJ, Nejstgaard JC, Alderkamp AC (2007a) Colony size, cell number, carbon and nitrogen contents of Phaeocystis pouchetii from western Norway. J Plankton Res (in press)

Verity PG, Zirbel MJ, Nejstgaard JC (2007b) Formation of very young colonies by Phaeocystis pouchetii from western Norway. Aquat Microb Ecol 47:267-274

Verity PG, Brussard CP, Nejstgaard JC, van Leeuwe M, Lancelot C, Medlin LK (2007c) Current understanding of Phaeocystis ecology and biogeochemistry,

Editorial responsibility: Curtis Suttle,

Vancouver, British Columbia, Canada and perspectives for future research. Biogeochemistry 83:311-330

Wassmann P, Vernet M, Mitchell BG, Rey F (1990) Mass sedimentation of Phaeocystis pouchetii in the Barents Sea. Mar Ecol Prog Ser 66:183-195

Wassmann P, Ratkova T, Reigstad M (2005) The contribution of single and colonial cells of Phaeocystis pouchetii to spring and summer blooms in the north-eastern North Atlantic. Harmful Algae 4:823-840

Whipple SJ, Patten BC, Verity PG (2005) Colony growth and evidence for colony multiplication in Phaeocystis pouchetii (Prymnesiophyceae) isolated from mesocosm blooms. J Plankton Res 27:495-501

Wommack KE, Colwell RR (2000) Virioplankton: viruses in aquatic ecosystems. Microbiol Mol Biol Rev 64(1):69

Zingone A (1995) The role of viruses in the dynamics of phytoplankton blooms. G Bot Ital 129:415-423

Submitted: September 5, 2006; Accepted: May 18, 2007

Proofs received from author(s): June 23, 2007 